\title{
PENGGUNAAN ALAT PENDUKUNG PRAKTIK PADA KOMPETENSI MENGUNAKAN MESIN BUBUT KOMPLEKS
}

\author{
Muhamad A. S. Hidayat ${ }^{1}$, Aam Hamdani' ${ }^{2}$, Ridwan A. M. Noor ${ }^{3}$ \\ Universitas Pendidikan Indonesia \\ Jl. Dr. Setiabudhi No.229 Bandung 40154 \\ muhamadarifsaifulhidayat@gmail.com
}

\begin{abstract}
ABSTRAK
Penelitian ini bertujuan untuk mengetahui bagaimana penggunaan alat praktik pada kompetensi mempergunakan mesin bubut kompleks di bengkel pemesinan SMK Negeri 2 Kota Bandung. Metode penelitian yang digunakan pada penelitian ini yaitu metode deskriptif. Teknik pengumpulan data yang digunakan yaitu wawancara, observasi penggunaan alat praktik membubut kompleks, serta dokumentasi inventaris alat yang terdapat di bengkel pemesinan. Hasil penelitian menunjukan penggunaan alat praktik pada kompetensi mempergunakan mesin bubut kompleks di bengkel pemesinan SMK Negeri 2 Kota Bandung berada pada kategori cukup baik. Faktor yang mempengaruhi kualitas produk kerja yaitu ketersediaan mesin serta peralatan praktik, pahat yang digunakan, bahan benda kerja, pemilihan parameter pemotongan, dan kemampuan siswa. Implikasi dari penelitian ini adalah pengadaan sarana dan prasarana yang sesuai dengan kebutuhan merupakan hal utama yang harus dilakukan, penyediaan dan perawatan alat praktik harus lebih ditingkatkan agar siswa mendapatkan pengalaman praktik yang lebih banyak sehingga siswa mampu memenuhi tuntutan kompetensi.
\end{abstract}

Kata kunci: efisiensi, rasio, pemesinan, membubut kompleks.

\section{PENDAHULUAN}

Pendidikan Kejuruan merupakan salah satu jenis pendidikan yang banyak diminati di Indonesia, karena pendidikan kejuruan berorientasi pada kompetensi dari peserta didik dan lulusan dari pendidikan kejuruan dipertaruhkan kesiapannya untuk bekerja. Pendidikan kejuruan sebagai salah satu bagian dari sistem pendidikan nasional memainkan peran strategis bagi terwujudnya angkatan tenaga kerja nasional yang terampil. Setiap lulusan SMK memang ditempah untuk menjadi sumber daya manusia yang siap pakai. Lulusan pendidikan kejuruan diharapkan dapat menjadi individu yang produktif yang mampu bekerja menjadi tenaga kerja menengah dan memiliki kesiapan untuk menghadapi persaingan kerja. Pada perkembangannya, SMK selalu mengikuti kebutuhan Dunia Usaha dan Dunia Industri (DU/DI). Oleh karena itu pengembangan kurikulum untuk SMK selalu mengikuti kebutuhan Dunia Usaha dan Dunia Industri (DU/DI) sehingga diharapkan dapat terciptanya lulusan-lulusan SMK yang siap kerja sesuai dengan kebutuhan Dunia Usaha dan Dunia Industri (DU/DI).

\footnotetext{
${ }^{1}$ Mahasiswa Departemen Pendidikan Teknik Mesin FPTK, UPI

2 Dosen Departemen Pendidikan Teknik Mesin FPTK, UPI

${ }^{3}$ Dosen Departemen Pendidikan Teknik Mesin FPTK, UPI
} 
Kenyataan yang terjadi pada saat ini yaitu masih banyaknya lulusan pendidikan kejuruan yang belum mampu menghadapi persaingan kerja. Menurut survei Angkatan Kerja Nasional (Sakernas) dari Badan Pusat Statistik (BPS) bahwa pada Agustus 2015 (lihat gambar 1.1), tingkat pengangguran terbuka (TPT) tertinggi kedua ada pada jenjang pendidikan Sekolah Menengah Kejuruan (SMK), yaitu sebesar 20,76\% dimana jumlah TPT pada Agustus 2015 sebesar 7,56 juta orang. Itu berarti terdapat 1.569.690 jiwa lulusan SMK yang menganggur pada Agustus 2015.

Salah satu penyebabnya adalah kurangnya pengalaman praktikum siswa di sekolah. Pengaman kerja sangat berpengaruh secara positif terhadap produktivitas kerja seseorang (Itafia, 2014). Banyak faktor yang menyebabkan kurangnya pengalaman praktikum siswa di sekolah, salah satu yang paling banyak ditemukan adalah terbatasnya jumlah sarana dimiliki oleh SMK. Ketidaksesuaian jumlah alat sangat mempengaruhi jam praktikum di SMK. Tidak sedikit SMK yang belum memenuhi standar ketentuan sarana dan prasarana yang menyebabkan lulusan SMK banyak yang belum memenuhi tuntutan Kompetensi Industri khususnya di bidang pemesinan. Dengan sarana dan prasarana yang terbatas karena tidak diperbaharui. Apabila ini dibiarkan, maka dapat dipastikan kualitas pendidikan tidak akan bertambah baik kedepannya (Komite Nasional Pendidikan, 2014).

Sarana dan prasarana untuk pendidikan kejuruan merupakan hal yang sangat penting, karena proses kegiatan pembelajaran di SMK meliputi pembelajaran teori dan pembelajaran praktik. Untuk menunjang kegiatan praktik di SMK diperlukan sarana dan prasana untuk menunjang proses pembelajaran praktik, seperti workshop serta perlengkapan alat praktiknya. Fasilitas pembelajaran seperti kebutuhan modul analisis dan peralatan, ketersediaan ruangan serta jumlah guru yang cukup. Khusus untuk kebutuhan alat dan bahan harus mengacu pada rasio kecukupan satu siswa satu alat dan bahan serta memadai dalam jenis dan jumlah sesuai dengan tuntutan kompetensi. Kebutuhan alat dan bahan untuk praktikum idealnya harus mengacu pada rasio satu siswa satu alat. Keadaan alat yang digunakan untuk praktikum harus memadai dalam jenis dan jumlah. Hal ini bertujuan agar penggunaan alat praktikum dilakukan secara efektif sehingga target pembelajaran bisa tercapai, karena merupakan suatu kerugian jika terdapat siswa yang menganggur karena tidak kebagian pemakaian alat.

Hasil observasi di PT. Kawani Bandung, alat produksi disediakan sesuai dengan kebutuhan proses produksi. Jumlah alat utama disesuaikan dengan jumlah operator, dimana setiap operator disediakan satu mesin dengan kondisi siap pakai beserta alat bantu yang 
lengkap untuk proses produksi. Hal ini dilakukan agar hasil produksi sesuai dengan target yang dicapai oleh tuntutan industri baik waktu produksi, maupun hasil produksi. Selain itu, persediaan alat yang lengkap bertujuan agar operator dapat fokus dengan job yang diberikan oleh industri. Hasil observasi di PPPPTK-BMTI Bandung, alat praktik untuk pelatihan disediakan sesuai dengan jenis pekerjaan yang akan dilakukan. Adapun peserta praktik merupakan guru-guru sekolah yang dilatih agar kompeten dalam mengajar. Pada pelaksanaan praktik, setiap operator diberi alat yang lengkap yang disimpan pada toolbox. Hal ini dilakukan agar operator dapat menyelesaikan pekerjaan dengan mudah dan sesuai dengan target yang telah ditentukan.

Hasil wawancara dengan kepala bengkel pemesinan di SMK Negeri 2 Kota Bandung didapatkan informasi bahwa kelemahan dari Sekolah Menengah Kejuruan di bidang Teknik Mesin di Indonesia pada umumnya terdapat pada hal penyediaan alat. Kurangnya alat praktikum sangat mempengaruhi proses pembelajaran praktek pemesinan, khususnya praktek pemesinan bubut kompleks di SMK Negeri 2 Kota Bandung. Salah satu dampak yang sangat terlihat karena kurangnya ketersediaan alat yaitu pekerjaan menjadi lebih lambat dari waktu yang telah direncanakan, hal ini terjadi karena terdapat siswa yang masih saling menunggu untuk menggunakan alat yang dibutuhkan. Keadaan seperti ini sangat berbanding terbalik dengan keadaan di dunia industri yang menuntut proses produksi harus sesuai dengan waktu yang telah ditentukan.

Keadaan di SMK Negeri 2 tidak jauh berbeda dengan hasil penelitian dari Ito Ismanto. Terdapat 7 orang siswa atau $23 \%$ siswa berada pada kategori sangat jelek. Terdapat beberapa faktor yang menyebabkan siswa berada pada kategori Jelek dan Sangat Jelek. Salah satu faktor yang menyebabkan siswa berada pada kategori tersebut yaitu keadaan alat praktikum. Mesin presisi biasanya akan mempunyai karakteristik variabilitas proses yang kecil, namun sebaliknya mesin produksi yang tidak presisi cenderung untuk menghasilkan produk dengan variabilitas yang besar (Rohim, 2001). Hal inilah yang menyebabkan kualitas produk hasil kerja menjadi tidak maksimal dan sering tidak diperhatikan oleh siswa maupun guru praktikan yang ada di sekolah.

Dari hasil penelitian tersebut muncul pertanyaan, apakah lulusan SMK mampu bersaing di dunia industri. Jika pada kenyataannya banyak lulusan SMK tidak terserap di industri, maka akan semakin banyak pengangguran. 


\section{METODE PENELITIAN}

Metode digunakan merupakan penelitian deskriptif dengan pendekatan analisis. Penelitian ini berusaha mendeskripsikan informasi yang ada sesuai dengan variabel yang diteliti. Penelitian ini bukan untuk menguji hipotesis, tetapi untuk mendeskripsikan fenomena yang muncul di lapangan. Penelitian deskriptif adalah metode penelitian yang berusaha menggambarkan dan menginterpretasi obyek sesuai dengan apa adanya.

\section{HASIL PENELITIAN}

Kondisi peralatan di bengkel pemesinan SMK Negeri 2 Kota Bandung khususnya untuk kegiatan praktik kerja bubut dapat secara umum berada pada kondisi lengkap dan sangat layak pakai. Pada pelaksanaan pembelajaran praktik, alat yang disediakan adalah alat yang hanya dibutuhkan sesuai dengan job sheet yang akan dikerjakan. Jenis pekerjaan (job) untuk teknik pemesinan bubut konvensional dibagi menjadi 4 jenis pekerjaan, yaitu: (JS 1) tarikan handle, (JS 2) ulir ganda, (JS 3) ulir segi empat, dan (JS 4) poros eksentrik. Job sheet 1 (tarikan handle) terdiri dari beberapa jenis teknik pembubutan, yaitu bubut rata, bubut champer, bubut ulir, bubut dalam, tirus, ulir, dan kartel.

Secara umum alat yang tersedia telah memenuhi kebutuhan pada job sheet 1 , namun secara kuantitas alat yang tersedia masih banyak yang belum sebanding dengan jumlah siswa yang sedang praktik dalam 1 kelompok. Berdasarkan ketentuan standar jumlah alat yang dikeluarkan oleh BSNP, maka idealnya perbandingan antara jumlah alat dengan jumlah siswa yaitu 1 siswa 1 alat.

Pada pelaksanaan praktik pemesinan bubut, beberapa alat yang disediakan telah mengacu kepada perbandingan satu siswa satu alat, tetapi terdapat beberapa alat yang belum mengacu kepada satu siswa satu alat. Hal ini dikarenakan alat tersebut hanya digunakan pada bagian langkah kerja tertentu. Alat pendukung praktik yang disediakan sebagian besar memiliki nilai efisiensi yang sangat tinggi yaitu diatas 90\%. Adapun kriteria nilai efisiensi penggunaan yang baik adalah berkisar antara 70\% - 90\% (Achir, 1995). kriteria nilai efisiensi penggunaan alat yang baik, maka dapat diketahui bahwa jumlah alat yang disediakan berada pada kategori tidak efisien karena nilainya sebagian besar diatas $90 \%$. Adapun jumlah alat yang tersedia untuk job sheet 1 serta nilai efisiensi dari penggunaan alat dijelaskan pada tabel 1. 
Tabel 1. Alat yang disediakan dan nilai efisiensi penggunaan alat

\begin{tabular}{|c|l|c|c|c|}
\hline No & Nama Alat & $\begin{array}{c}\text { Jumlah } \\
\text { Tersedia }\end{array}$ & $\begin{array}{c}\text { Jumlah } \\
\text { Siswa }\end{array}$ & $\begin{array}{c}\text { \% Efsiensi } \\
\text { Alat }\end{array}$ \\
\hline 1 & Mesin bubut & 11 & 9 & 71,59 \\
\hline 2 & Senter putar & 10 & 9 & 78,75 \\
\hline 3 & Chuck drill & 3 & 9 & 262,50 \\
\hline 4 & Kunci toolpost & 9 & 9 & 87,50 \\
\hline 5 & Kunci chuck & 9 & 9 & 87,50 \\
\hline 6 & Kunci chuck drill & 2 & 9 & 393,75 \\
\hline 7 & Kunci L 5 & 2 & 9 & 393,75 \\
\hline 8 & Kunci L 7 & 2 & 9 & 393,75 \\
\hline 9 & Kunci pas 12-13 & 1 & 9 & 787,50 \\
\hline 10 & Kunci pas 14-17 & 1 & 9 & 787,50 \\
\hline 11 & Pahat rata kanan & 12 & 9 & 65,63 \\
\hline 12 & Pahat alur & 6 & 9 & 131,25 \\
\hline 13 & Pahat ulir & 6 & 9 & 131,25 \\
\hline 14 & Pahat bubut dalam & 6 & 9 & 131,25 \\
\hline 15 & Mata bor 6 & 1 & 9 & 787,50 \\
\hline 16 & Mata bor 10 & 1 & 9 & 787,50 \\
\hline 17 & Mata bor 12 & 1 & 9 & 787,50 \\
\hline 18 & Bor senter & 2 & 9 & 393,75 \\
\hline 19 & Kartel & 2 & 9 & 393,75 \\
\hline 20 & Mistar sorong & 9 & 9 & 87,50 \\
\hline 21 & Kacamata & 9 & 9 & 87,50 \\
\hline & & & & \\
\hline
\end{tabular}

Proses kerja praktik pemesinan bubut terdiri dari 5 aspek penting, hal ini disesuaikan dengan kriteria kompetensi yang ditetapkan oleh BSNP, yaitu: persiapan kerja, proses kerja, hasil kerja, nilai sikap dan waktu. Hasil penilaian kelompok nilai siswa, diketahui bahwa sebagian besar siswa berada pada kategori cukup dan memiliki persentase sebesar 50\%. Hasil perhitungan nilai kerja praktik membubut siswa diketahui bahwa $11,7 \%$ sangat baik, 11,7\% baik, 50\% cuku , 23,5 kurang dan 2,9 sangat kurang. Nilai tersebut mengindikasikan bahwa secara rata-rata sampel siswa kelas XII Teknik Pemesinan yang mengikuti praktik telah cukup memiliki kompetensi pada praktik kerja membubut kompleks, namun masih terdapat beberapa kekurangan sehingga belum dapat mencapai nilai pada kategori yang baik. 


\section{PEMBAHASAN}

Hasil observasi diketahui bahwa jenis alat pendukung praktik kerja bubut yang tersedia di bengkel pemesinan SMK Negeri 2 Kota Bandung sudah memenuhi kriteria standar pengadaan alat. Jumlah mesin bubut yang tersedia yaitu 11 dan jumlah siswa pada setiap kelompok yaitu 8 sampai 9 siswa, hal ini sesuai dengan standar peraturan yang ditetapkan Pemerintah tentang jumlah peralatan minimum untuk pekerjaan bubut logam yaitu minimal untuk 8 peserta didik. Kondisi dari berbagai jenis alat pendukung praktik membubut kompleks sebagian besar berada pada kondisi sangat layak dan siap pakai. ketersediaan alat yaitu kuantitas dari jumlah alat yang tersedia beragam. Secara kuantitas, alat yang tersedia jumlahnya bervariatif. Ada yang berjumlah banyak dan ada pula yang berjumlah sedikit. Jumlah alat yang sedikit mengganggu keberlangsungan praktik dikarenakan jumlah ketersediaan alat yang sedikit sehingga pada pelaksanaannya penggunaan alat dilakukan secara bergantian. Penggunaan alat secara bergantian berdampak pada lamanya waktu praktik serta keadaan praktik yang kurang kondusif.

Data efisiensi penggunaan alat diketahui bahwa sebagian besar jumlah alat yang disediakan berada pada kategori tidak efisien karena nilainya sebagian di atas $90 \%$. Jumlah peralatan yang tersedia mempengaruhi nilai efisiensi penggunaan alat, semakin sedikit kuantitas alat yang tersedia, maka semakin besar nilai efisiensinya dan jauh dari nilai kriteria ideal dari efisiensi penggunaan alat, yaitu 70\% - 90\%. Sedangkan semakin banyak jumlah alat, maka semakin kecil nilai efisiensi penggunaan alat. Dimana alat yang berjumlah sedikit seperti mata bor yang berjumlah 1 unit memiliki nilai efisiensi di atas $100 \%$. Sedangkan alat yang berjumlah lebih banyak seperti mesin bubut yang berjumlah 11 unit memiliki nilai efisiensi 71,59\%. Perhitungan nilai efisiensi penggunaan alat praktikum sangat penting diketahui agar penyediaan alat praktik dikelola dengan baik. Suatu alat dapat dikatakan memiliki nilai efisiensi yang baik apabila dapat memenuhi kriteria antara jumlah frekuensi keterpakaian dengan ketersedian alat berimbang, sehingga tidak terdapat kondisi dimana alat tidak terpakai karena berlebih atau bahkan rusak akibat dipakai secara berlebih.

Proses pembelajaran praktik pemesinan bubut konvensional di SMK Negeri 2 Kota Bandung terdiri dari 2 bagian, yaitu pembelajaran teori dan pembelajaran praktik. Pembelajaran teori dilakukan di kelas dan di bengkel. Pembelajaran teori dilakukan untuk menunjang pembelajaran praktik. Sebelum proses praktik kerja, siswa dituntut untuk dapat menganalisa job sheet berupa gambar kerja, langkah kerja, waktu kerja, serta alat yang 
akan digunakan. Siswa dituntut untuk dapat membuat rencana kerja sehingga dapat menentukan waktu yang akan digunakan pada proses kerja praktik dalam setiap job. Waktu yang praktik ditentukan oleh siswa sesuai dengan rencana kerja yang telah dibuat.

Penilaian hasil observasi kerja praktik dapat diketahui bahwa beberapa siswa kelas XII masih belum memenuhi kriteria kompetensi mempergunakan mesin bubut kompleks. Salah satu aspek yang sangat terlihat yaitu aspek waktu kerja. Berdasarkan data hasil observasi praktik diketahui bahwa dari jumlah 34 siswa yang mengikuti praktik hanya 8 siswa yang menyelesaikan pekerjaan sesuai dengan waktu yang direncanakan. Ketidaksesuaian waktu penyelesaian pekerjaan salah satunya disebabkan oleh faktor terbatasnya jumlah alat yang tersedia pada saat praktik. Waktu kerja merupakan hal yang sangat penting di dalam suatu pekerjaan. Ketepatan waktu dalam bekerja mengindikasikan bahwa seorang pekerja telah kompeten dalam suatu bidang pekerjaan yang ditekuninya. Selain aspek waktu, aspek hasil kerja merupakan hal penting dari suatu proses kerja dan mempunyai bobot nilai yang cukup tinggi. Beberapa faktor yang mempengaruhi kualitas produk kerja yaitu mesin serta peralatan praktik, pahat yang digunakan, bahan benda kerja, pemilihan parameter pemotongan, dan kemampuan siswa.

Faktor yang pertama yaitu mesin dan peralatan praktik, dalam hal ini yaitu kualitas dan kuantitas peralatan praktik. Kualitas alat menjadi hal yang sangat utama, peralatan yang baik yaitu alat yang berada pada kondisi yang baik dan siap pakai. Selain itu, pengadaan alat pendukung praktik yang sesuai dengan kebutuhan kerja harus diperhatikan. Ketersediaan alat pendukung praktik yang lengkap dan dengan jumlah yang sesuai kebutuhan sangat membantu proses kerja praktik. Faktor yang kedua yaitu pahat yang digunakan. Kualitas pembubutan logam sangat dipengaruhi oleh jenis pahat yang digunakan. Pahat yang digunakan pada umumnya yaitu pahat HSS dan pahat karbida. Pahat HSS mempunyai keunggulan dari sisi ekonomi karena jenis pahat ini relatif lebih murah dibandingkan pahat karbida, namun dari efisiensi produktivitas kerja, penggunaan pahat bubut jenis ini kurang menguntungkan. Permukaan pahat HSS cepat aus sehingga ketajamannya cepat sekali menurun. Bila pahat bubut mulai menurun ketajamannya, maka kualitas permukaan benda kerja dan ketepatan ukuran kerja akan terpengaruh. Pahat karbida memiliki keunggulan diantaranya adalah resistensi terhadap deformasi termal atau perubahan bentuk kerja karena panas, ketahanan keausan, dan memiliki torsi kekuatan dua kali lipat lebih tinggi dari HSS. Kelemahan dari pahat karbida yaitu sulit di asah, sehingga pahat jenis ini tidak dapat digunakan kembali ketika pahat sudah mulai aus, berbeda 
dengan jenis pahat HSS dimana pahat jenis ini dapat diasah kembali ketika pahat sudah mulai aus.

Faktor ketiga yaitu bahan benda kerja yang digunakan. Bahan kerja biasanya berupa bahan-bahan logam fero seperti baja lunak (mild steel), besi tuang (cast iron), serta logam non fero seperti perunggu, tembaga, kuningan, dan alumunium. Setiap jenis logam mempunyai tingkat kekerasan yang berbeda. Pengetahuan tentang profil tingkat kekerasan bahan benda kerja dapat membantu operator untuk menentukan parameter pemotongan pada proses kerja membubut. Semakin tinggi tingkat kekerasan suatu bahan benda kerja, maka akan semakin lama waktu yang dibutuhkan operator untuk menyelesaikan benda yang diinginkan. Faktor yang keempat yaitu menentukan parameter pemotongan. Parameter pemotongan dapat diketahui apabila pahat dan bahan benda kerja yang akan digunakan telah ditentukan. Cara menentukan parameter pemotongan yaitu dengan cara mnentukan kecepatan pemakanan (feed), kecepatan putaran mesin bubut (revolution per menit), serta kecepatan potong (cutting speed). Penentuan kecepatan potong (cutting speed) harus berdasarkan kriteria jenis bahan benda kerja dan jenis pahat yang digunakan.

Faktor yang kelima yaitu kemampuan siswa pada persiapan pegoperasian mesin bubut (setting machine). Persiapan mesin sebagai alat utama pada proses membubut harus dilakukan dengan sebaik-baiknya, dimulai dari pemeriksaan kondisi mesin, pemeriksaan ketelitian mesin, pengaturan putaran, pengaturan pahat, serta pengondisian area kerja. Perbedaan operator di dunia industri dengan siswa SMK yaitu pengalaman kerja yang menyebabkan operator di industri lebih terampil dalam mengatur mesin, seperti pengaturan kecepatan putaran dan pengaturan alat potong. Faktor lain yang mempengaruhi waktu dan kualitas benda hasil kerja yaitu penggunaan pendingin (coolant) pada proses pemotongan serta jenis pekerjaan yang dilakukan (Rohim, 2001). Penggunaan pendingin (coolant) pada proses pemotongan akan membantu operator agar mendapatkan hasil benda kerja yang baik. Suhu panas yang timbul akibat terjadinya deformasi plastis pada proses bubut (terlepasnya geram dari bahan benda kerja) sehingga berpengaruh terhadap umur pahat. Selain itu, jenis pekerjaan yang dilakukan mempengaruhi waktu kerja, karena tingkat kesulitan setiap jenis kerja berbeda.

\section{KESIMPULAN}

Kesimpulan penelitian ini yaitu rasio jumlah alat yang tersedia dengan jumlah siswa ketika praktik sebagian telah memenuhi kriteria rasio ideal yaitu 1 siswa 1 alat. 
Namun, beberapa alat masih belum memenuhi kriteria rasio ideal yaitu 1 siswa 1 alat. Nilai efisiensi dari penggunaan alat yang disediakan pada saat praktik job sheet 1 sebagian besar berada pada kategori tidak efisien karena nilainya sebagian besar nilainya diatas $90 \%$. Penggunaan alat praktik pada kompetensi mempergunakan mesin bubut kompleks di bengkel pemesinan SMK Negeri 2 Kota Bandung berada pada kategori cukup baik. Faktor yang mempengaruhi kualitas produk kerja yaitu ketersediaan mesin serta peralatan praktik, pahat yang digunakan, bahan benda kerja, pemilihan parameter pemotongan, dan kemampuan siswa.

\section{REFERENSI}

Achir, B. (1995). Merencanakan Kebutuhan Fasilitas Pelajaran Praktek dan Optimasi Pemakaiannya. Bandung: PPPGT.

Itafia, Y. (2014). Pengaruh Pengalaman Kerja dan Kepuasan Kerja Terhadap Produktivitas Kerja Karyawan pada Industri Tenun. Jurnal Bisma universitas Pendidikan Ganesha. Volume 2.

Komite Nasional Pendidikan. (2014). Permasalahan Pendidikan Serta Rekomendasi untuk Pemerintahan Baru. Komite Nasional Pendidikan.

Rohim, T. (2001). Spesifikasi, Metrologi, \& Control Kualitas Geometrik. Jilid 1 Bandung: ITB.

Sakernas. (2015). Data Pengangguran Terbuka Menurut Pendidikan Tertinggi yang Ditamatkan Per Agustus 2015. (Online). Diakses dari: www.bps.go.id. 